\title{
Assessing Children's Spelling
}

\section{Ruth McQuirter Scott}

M How can I evaluate my students' spelling skills when the curriculum doesn't even tell me what to teach?" This question was posed during an in-service session I provided for teachers not long after the introduction of a new Language curriculum to Ontario schools in 1997. Although the curriculum document mentions spelling at each grade level, the expectations are quite generic and do not show much variation from grade to grade. If assessment and evaluation are to be tied to instruction, how can teachers, in the absence of clear benchmarks, be sure their reporting practices are valid?

The following suggestions do not provide definitive answers about what constitutes a level 3 or 4 in spelling at each grade level. They do, however, present a number of strategies teachers can use when assessing a child's spelling development. By employing a combination of these approaches, the teacher can develop a profile of the child's spelling skills that will be more comprehensive and meaningful than any one evaluation instrument, whether it be a standardized measure such as the WRAT or weekly spelling quizzes. The information in this profile can then be used by teachers with greater confidence for purposes of instruction and reporting.

\section{Be aware of how children learn to spell.}

There has been ample research since the early 1980 's tracing children's spelling development. The work of Henderson (1981;1990), Gentry (1993), and Templeton (1983), among others, describes the process of learning to spell across grade levels, and can be used by teachers to assess the writing samples of children. These researchers point to increasingly sophisticated strategies used by children as they master the concepts underlying the spelling system of English. A variety of professional texts present these findings in ways applicable to the classroom (Gentry, 1993; Phenix \& Scott-Dunne, 1991; Scott, 1993; Tarasoff, 1990, 1992).

Most reputable spelling programs authorized for use in Ontario schools are based on the research referred to above. The scope and sequence outlined for each grade level in student texts usually parallels the general developmental sequence described by cognitive psychologists such as Henderson (1990), Read (1970) and Beers (1977). Whether or not a teacher or school district decides to use a published spelling program, a glance at the tables of contents will help teachers set realistic expectations for their grade level. These decisions will then provide some guidelines for determining whether specific students are spelling within the range of skills typical for that grade.

\section{Use student writing as a pri- mary assessment tool.}

Gentry (1993, p.39) maintains that "each time a child or adult invents a spelling, he or she produces a telling snapshot of how the mind conceives of spelling." When teachers go beyond simply marking spelling attempts as correct or incorrect, they open themselves to a richer understanding of their students' spelling development.
Kelli, age 8, writes a thank you note to her aunt. "You'r garden party was fun. It was the best party eaver." It would be easy to circle the attempts "You'r" and "eaver" as incorrect and leave it at that. By looking at these spellings analytically, however, we learn more about Kelli as a speller. Her attempt to spell "Your" as "You' $r$ " shows that Kelli is aware of the use of an apostrophe to spell some words. She isn't sure how this pattern works, but her experimentation is more sophisticated than that of the child who sounds the word out and writes "Yor." Similarly, Kelli's spelling of "ever" as "eaver" suggests she knows the short $e$ sound is sometimes spelled with the vowel combination ea, as in "heaven." She is unaware that this pattern for spelling short $\mathrm{e}$ is not found at the beginning of words, but at least she is thinking about how the spelling system works.

When teachers begin to assess their students' spelling attempts within a developmental framework, they realize that the quality of a child's misspelling is often more revealing than whether or not the spelling is correct.

\section{Gather samples of writing from a variety of sources.}

There are ample opportunities for teachers to observe the spelling development of their students. Each of the following categories provides an important perspective on spelling assessment.

\section{a. Unedited writing:}

By viewing a child's everyday work, early drafts in writing folders, journal entries, and so forth, the teacher can see what the child intuitively knows about the spelling system as well as the extent of the child's "spelling vocabulary." Of course, these pieces should not be "marked" for spelling, 
but they do provide a rich source of assessment information.

\section{b. Polished writing:}

A piece of writing that has been taken through the stages of the writing process should contain very few spelling errors. The state of editing can reveal how well the child is able to proofread, the care taken to do so, and the general level of vocabulary used. Some children may have error-free writing, but have used only simple, easily spelled words. Instead of trying to spell frustrated, for example, they may substitute the single-syllable word mad. If a child's written vocabulary is significantly less sophisticated than his or her oral language, it may be a clue about insecurities around spelling.

c. Dictated words:

The advantage of dictating words from teacher-selected lists is that age-appropriate words can be included. Furthermore, if a spelling text is a source of these lists, they are likely to reflect various spelling concepts. Each unit is often based on a concept such as vowel patterns, adding endings, and so forth. Other available lists may be comprised of frequently used or misspelled words at various grade levels. Teachers can also dictate words related to themes, content areas, or word walls compiled with the students. When such lists are dictated, children are forced to move beyond the simple words they may choose to use in their writing and to apply spelling strategies to words they are unsure of how to spell.

When using lists as a source of spelling assessment, it is often helpful to conduct a pre-test in which the words are dictated before the children have a chance to study them. This strategy has a number of advantages. It shows the teacher the child's current knowledge of these words and the strategies the child employs to spell unfamiliar words. It also helps to isolate the words the child needs to study, thereby making the learning period more efficient. The class can then identify difficult parts of each word and brainstorm strategies for spelling them correctly. A post-test can then focus on improvement from the pre-test and identify words still needing to be studied.

\section{Use a cloze procedure to see patterns of errors.}

The cloze strategy for noting misspellings helps teachers see patterns in their students' spelling attempts. Instead of marking a response as either correct or incorrect, recopy the correct letters and leave spaces for the others. For example, ned (need) becomes ne _ d, baskitball (basketball) becomes bask tball, and so forth. By observing a sampling of a child's spelling errors scored in this way, the teacher can see a picture emerging. Questions such as the following can guide these observations:

- Are all sounds represented?

- Are spellings of sounds phonetically acceptable? e.g. wuz for was is phonetically accurate, although misspelled.

- Does the attempt contain the correct number of syllables?

- Are there problems with reversal of letters?

- Are errors typically at the beginning/middle/end of words?

- Are morphemes spelled correctly? e.g. -ed for past tense; -s or -es for plural

- Are silent letters routinely omitted?
- Do schwa vowels (vowels in unstressed syllables) create problems? e.g. helmut for helmet.

The cloze strategy can be employed in many aspects of the writing program. In editing conferences, teachers can point out spelling errors in draft pieces without resorting to circling errors. This will help children zero in on the nature of the misspelling. When word lists are dictated in pre-test conditions, the cloze procedure helps students isolate the features of the word that need to be studied and usually reassures them that most of the letters have been spelled correctly.

\section{Assess spelling growth over time}

If Gentry is correct in describing spelling attempts as "snapshots of how the mind conceives of spelling," then a collection of writing gathered over time can serve as an album of spelling growth. Teachers can apply the same cloze procedures described above to look for patterns of spelling errors at various times in the school year and note how these patterns change. In most cases, the patterns will reveal increasingly sophisticated strategies for handling the complexities of the English spelling system. The child, for example, who spells jumped in September as jumpt, but a few months later spells all regular past tenses with the -ed morpheme, has made a significant leap in spelling development. She has discarded her hypothesis that words are spelled just as they sound, and has understood that certain word parts, such as the -ed marker for past tenses, are used to signify meaning even if they do not sound as they are spelled. It is this understanding that allows the child to spell the past tense of jumped as -ed even though it sounds like / $t$ /. 
Another way of assessing spelling growth is to take an unedited passage of each child's writing from early in the school year and dictate the same passage several months later. By examining both the number and quality of misspellings at the two time periods, teachers can catch a glimpse of how the child's spelling strategies have progressed. This information would provide an excellent vehicle for parent/teacher conferences and would also serve as a helpful discussion starter between the teacher and the student.

\section{Encourage students to reflect on their own spelling develop-} ment

Many of the teaching strategies described previously can be adapted for student use. It is important that children learn to take responsibility for their own spelling growth and to develop both a "spelling conscience" (a sense that spelling matters) and a "spelling consciousness" (a metacognitive understanding of their spelling strategies). Over time, children can become the best assessors of their own spelling growth.

The following suggestions will help to involve students in a meaningful way in spelling assessment.

- Use editing conferences and day-to-day writing situations to engage in conversations with individual students about their spelling.

If a child spells climb as clime, show him which letters are correct using the cloze procedure (clim_), and acknowledge that his attempt makes sense when sounding out the word. Ask him why he decided to spell the word this way. If he does not know the correct spelling, either let him find it elsewhere, or provide it and explain the challenge of the silent $b$. Ask if he can think of a strategy for remembering this word in the future (say the word as if the $b$ is sounded; link it with other words ending in silent $b$ ). Note this word for future use with the class on a Word Wall or list of frequently misspelled words.

- Model the use of a variety of spelling strategies with the whole class.

When words are encountered throughout the day, in everyday writing, content subjects, spelling texts, or themes, ask students to suggest approaches to remembering the correct spelling. Every teacher periodically struggles with spelling; rather than covering up by substituting an easier word, enlist the help of students to come up with "tricks" to recall the difficult parts of the word. These quick discussions will enhance each student's metacognitive awareness of the spelling system and the processes involved in learning specific words.

- Instruct students in the use of the cloze procedure to highlight the features of words they have misspelled.

Alternatively, have spelling partners use cloze to edit one another's writing or mark pre and post-tests in dictated lists. Then have students recopy the words correctly and highlight in a different colour the letters that gave them difficulty. Spelling partners or small groups can then discuss specific spelling strategies to learn the highlighted letters.

- Encourage students to examine their misspellings and to look for patterns of errors.

If the children are using a spelling text, it is usually easier to link errors with specific spelling concepts, since most programs are organized around spelling patterns. In everyday writing, students can classify their mistakes as occurring at the beginning, middle, or ends of words.
- Structure time for students to examine their writing folios and to trace their growth in spelling over a period of time.

Many students will be pleasantly surprised to see how their spelling has improved over the course of a term or school year. A young child may notice that she no longer prints words without leaving spaces between them; older students may laugh that they once spelled the word vacation as vacashun, now that they have consolidated the spelling of the /shun/ ending.

- Ask students to set goals for their spelling.

These goals will reflect the nature of the classroom language program and the needs of the students. Some children may set specific targets for correctly spelling words on weekly spelling tests. Others may try to eliminate certain errors in their everyday writing. Still others may make a commitment to proofread their drafts more diligently when polishing their work. In each case, the student should set the goal and monitor progress toward attaining it.

\section{Conclusion}

The Ontario Curriculum, Grades $1-8$ : Language is vague regarding specific grade-by-grade expectations for spelling. Nevertheless, teachers are expected to assess this skill in their students, and are held accountable for effective spelling instruction. The suggestions in this article provide a framework for assessment of spelling that is based on extensive research on the developmental nature of learning to spell. By using a variety of sources to gather information about student spelling, teachers will be able to create a comprehensive spelling profile for each student. This information can then be used to plan and modify instruction and to communicate effectively with parents. 
adolescence and early adulthood: Implications for substance abuse prevention. Psychological Bulletin, 172,64-105.

Herman-Stahl. M. \& Petersen, A. C. (1996). The protective role of coping and social resources for depressive symptoms among young adolescents. Journal of Youth and Adolescence 25 733-753.

Hollister-Wagner, G. H., Foshee, V. A., \& Jackson, C. (2001). Adolescent aggression: Models of resiliency. Journal of Applied Social Psychology, 31(3), 445-466.

Jessor, R. (1993). Successful adolescent development among youth in high-risk settings. American Psychologist, 48, 117-126.

Jessor, R., Van Den Bos, J., Vanderryn, J., Costa, F.M., \& Turbin, M. S. (1995). Protective factors in adolescent problem behavior: Moderator effects and developmental change. Developmental Psychology, 31, 923-933.

Kupersmidt, J. B., \& Coie, J. D. (1990). Preadolescent peer status, aggression, and school adjustment as predictors of externalizing problems in adolescence. Child Development, 61, 1350-1362.

Luthar, S. S., Cicchetti, D., \& Becker, B. (2000). The construct of resilience: A critical evaluation and guidelines for future work. Child Development, 71(3), 543-562.

Masten, A. S., Best, K. M., \& Garmezy, N. (1990). Resiliency and development: Contributions from the study of children who overcome adversity. Development and Psychopathology, 2, 425-444.

Masten, A. S., \& Coatsworth, J. D. (1998). The development of competence in favorable and unfavorable environments: Lessons from research on successful children. American Psychologist, 53, 205-220.

Masten, A. S., \& Garmezy, N. (1985). Risk, vulnerability, and protective factors in developmental psychology. In B. Lahey \& A. Kazdin (Eds.), Advances in Clinical Child Psychology, Vol. 8 (pp. 1-52). New York, NY: Plenum Press.

Masten, A. S., Garmezy, N., Tellegen, A., Pellegrini, D. S., Larkin, K., \& Larsen, A. (1988). Competence and stress in school children: The moderating effects of individual and family qualities. Journal of Child Psychology and Psychiatry, 29, 745-764.

Masten, A. S., Hubbard, J. J., Gest, S. D., Tellegen, A., Garmezy, N., \& Ramirez, M.L. (1999). Competence in the context of adversity: Pathways to resilience and maladaptation from childhood to late adolescence. Development and Psychopathology, 11, 143-169.

Moran, P. B., \& Eckenrode, J. (1992). Protective personality characteristics among adolescents from maltreating homes. Child Abuse and Neglect, 16, 743-754.

Radke-Yarrow, M., \& Sherman, T. (1990). Hard growing: children who survive. In J. Rolf, A. S. Masten, D. Cicchetti, K. H. Nuechterlein and S. Weintraub (Eds.), Risk and protective factors in the development of psychopathology (pp. 97-119). New York: Cambridge University Press,

Rae-Grant, N., Thomas, B. H., Offord, D. R. \& Boyle, M. H. (1989). Risk, protective factors, and the prevalence of behavioral and emotional disorders in children and adolescents. Journal of American Academy of Child and Adolescent Psychiatry, 28(2), 262-268.

Resnick, M. D. (2000). Protective factors, resiliency, and healthy youth development. Adolescent Medicine, 11 (1), 157-164.

Rutter, M. (1985). Resilience in the face of adversity: Protective factors and resistance to psychiatric disorder. British Journal of Psychiatry, 147, 598-611.

Rutter, M. (1987). Psychosocial resilience and protective mechanisms. American Journal of Orthopsychiatry, 57(3), 316-331.

Rutter, M. (1990). Psychosocial resilience and protective mechanisms. In J. Rolf, A. S. Masten, D. Cicchetti, K. H. Nuechterlein and S. Weintraub (Eds.), Risk and protective factors in the development of psychopathology (pp. 181-214). New York: Cambridge University Press.

Scales, P. C. (1990). Developing capable young people: An alternative strategy for prevention programs. Journal of Early Adolescence, 10, 420-438.

Scales, P. C., \& Leffert, N. (1999). Developmental assets: A synthesis of the scientific research an adolescent development. Minneapolis, MN: Search Institute.

Werner, E. E. (1989). High-risk children in a young adulthood: A longitudinal study from birth to 32 years. American Journal of Orthopsychiatry, 59 (1), 72-81.

Werner, E. E., \& Smith, R. S. (1982). Vulnerable, but invincible: A longitudinal study of resilient children and youth. New York: McGraw-Hill.

Windle, M. (1992). A longitudinal study of stress buffering for adolescent problem behaviors. Developmental Psychology, 28, 522-530.

Wolkow, K. E. \& Ferguson, H. B. (2001). Community factors in the develop- ment of resiliency: Considerations and future directions. Community Mental Health Journal, 37(6), 489-498.

Wolin, S., \& Wolin, S. (1995). Resilience among children growing up in substance abusing families. Pediatric Clinics of North America, 42, 415-429.

Yates, M., \& Youniss, J. (1996). A developmental perspective on community service in adolescence. Social Development, $5,85-111$.

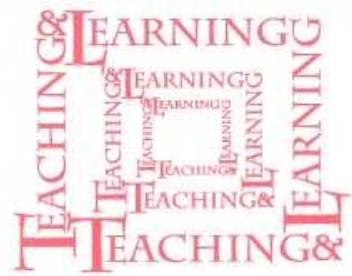

continued from $\mathrm{pg} .22$

\section{Assessing Children's Spelling}

Ruth McQuirter Scott

\section{References}

Beers, J. \& Henderson, E. (1977). A study of developing orthographic concepts among first grade children. Research in the Teaching of English, 11(2), 133-148.

Education Department of Western Australia (1995). First steps: Spelling resource book. Melbourne: Longman Australia.

Gentry, R. (1982). You can analyze developmental spelling. Teaching K-8, 15(9), 44-45.

Gentry, R. (1993). Teaching kids to spell. Portsmouth: Heinemann.

Henderson, E. (1981). Learning to read and spell. DeKalb: Northern Illinois University Press.

Henderson, E. (1990). Teaching spelling. Boston: Houghton Mifflin.

Phenix, J. \& Scott-Dunne, D. (1991). Spelling instruction that makes sense. Toronto: Pembroke.

Scott, R. (1993). Spelling: Sharing the secrets. Toronto: Gage.

Tarasoff, M. (1990). Spelling strategies you can teach. Victoria: Pixelart Graphics.

Tarasoff, M. (1992). A guide to children's spelling development for parents and teachers. Victoria: Active Learning Institute.

Templeton, S. (1983). Using the spelling/meaning connection to develop word knowledge in older students. Journal of Reading, 27(1), 8-15.

The Ontario Curriculum, Grades 1-8: Language (1997). 